\title{
Transition Metal Complexes of Omeprazole An Anti-Ulcerative Drug
}

\author{
Suman Malik ${ }^{1}$, Supriya Das ${ }^{1}$, Bharti Jain ${ }^{2}$ \\ ${ }^{1}$ Department of Chemistry, Sadhu Vaswani College, Bairagarh, Bhopal 462001 India \\ ${ }^{2}$ Department of Chemistry, Sarojni Naidu Government Girls College, Bhopal 462003 India \\ supriya.das.bpl@gmail.com
}

Omeprazole (OME) is a proton pump inhibitor (PPI). PPI's have enabled to improve the treatment of various acidpeptic disorders. OME is a weak base and it can form several complexes with transition and non-transitions metal ions. In the present paper, we are describing series of trantion metal complexes of omeprazole i.e.,5-methoxy2[(4methoxy-3,5dimethyl-2-pyridinyl)methylsulfinyl]-1H-benzimidazole with $\mathrm{Cu}^{\mathrm{II}}, \mathrm{Mn}^{\mathrm{II}}, \mathrm{Co}^{\mathrm{II}}, \mathrm{Ni}^{\mathrm{II}}, \mathrm{Fe}^{\mathrm{II}}, \mathrm{Zn}^{\mathrm{II}}$ and $\mathrm{Hg}^{\mathrm{II}}$. These complexes were characterized by elemental analysis, molar conductance, IR, NMR, magnetic susceptibility, UV-visible spectral studies, ESR, SEM and X-ray diffraction. Based on the above studies, the ligand behaves as bidentate $\mathrm{O}, \mathrm{N}$ donor and forms coordinate bonds through $\mathrm{C}=\mathrm{N}$ and $\mathrm{S}=\mathrm{O}$ groups .The complexes were found to non-electrolytic in nature on the basis of low values of molar conductance. Analytical data and stochiometry suggest ligand metal ratio of 2:1 for all the complexes. Electronic Spectra and Magnetic susceptibility measurements reveal octahedral geometry for $\mathrm{Mn}(\mathrm{II}), \mathrm{Co}(\mathrm{II}), \mathrm{Ni}(\mathrm{II}), \mathrm{Fe}(\mathrm{II})$ and $\mathrm{Cu}(\mathrm{II})$ complexes and tetrahedral for $\mathrm{Hg}(\mathrm{II})$ and $\mathrm{Zn}(\mathrm{II})$ complexes. Ligands and their metal complexes have been screened for their antibacterial and antifungal activities against bacteria Pseudomonas, Staphylococcus Aureus and fungi Aspergillus niger and A. flavous.

\section{INTRODUCTION}

A peptic ulcer, also known as PUD or peptic ulcer disease is an ulcer of an area of the gastrointestinal tract that is usually acidic and thus extremely painful .Ulcer results from a complex interplay of acid and chronic inflammation induced by $\mathrm{H}$. Pylori infection[1-2] .Most of the times, ulcers are associated with Helicobacter pylori, a spiral-shaped bacterium that lives in the acidic environment of the stomach. Reflux of acid and stomach contents can cause irritation or damage the lining of lower esophagus. If this damage is continuous, it can cause gastro-esophageal disease (GERD)[3-5]. Ulcers can also be caused or worsened by drugs such as aspirin and anti-inflammatory drugs. A class of drugs, called, proton pump inhibitors (PPIs) [6-8], blocks the production of acid by the stomach. PPIs are substituted benzimidazoles and are lipophilic weak bases that cross the parietal cell membrane and enter the acidic parietal cell canaliculus. In this acidic environment, the PPIs become protonated producing the activated sulphonamide from the drug that binds covalently with the $\mathrm{H}^{+}, \mathrm{K}^{+-}$-ATPase enzyme that results in irreversible inhibition of acid secretion by the proton pump. The drugs in the same class include omeprazole ,lansaprazole, rarbeprazole, and pantoprazole [9] and are used for the treatment in acid induced inflammation conditions and ulcers of the stomach and duodenum, gasteo-oesophageal reflux disease, all caused by stomach acid. The therapeutic activity of coordination compounds has been evaluated extensively[10-11] Some important examples of inorganic based drugs are metallocene anti-tumor complexes[12], gold antiarthritic compounds[13], lithium antidepressants[14]. In all these cases, work is largely focused on elucidating the mechanism of action of these complexes. Biological science literature reveals that the complexes of metallic salts are more potent and less toxic in many cases as compared to the parent drug[15]. Considering the importance of drugs and their complexes, it has been desired to synthesize and study the metal complexes of Omeprazole with metals. The present paper reports the synthesis, characterization and antimicrobial activity of a very common PPI, omeprazole, with first row transition metals like $\mathrm{Cu}^{\mathrm{II}}, \mathrm{Mn}^{\mathrm{II}}, \mathrm{Co}^{\mathrm{II}}, \mathrm{Ni}^{\mathrm{II}}, \mathrm{Fe}^{\mathrm{II}}, \mathrm{Zn}^{\mathrm{II}}{ }^{a n d \mathrm{Hg}^{\mathrm{II}}}$. 


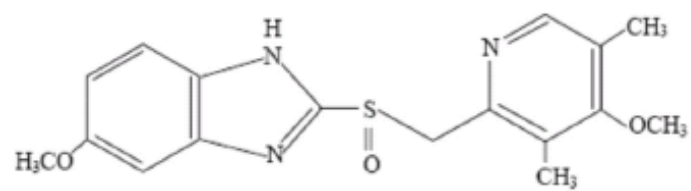

Figure 1: Structure of Omeprazole

\section{EXPERIMENTAL}

\section{Materials and methods}

All chemicals usedwere of AnalyticalGrade. Pure sample of omeprazole (molecular formula $\mathrm{C}_{17} \mathrm{H}_{19} \mathrm{~N}_{3} \mathrm{O}_{3} \mathrm{~S}$ ) with molecular weight 345.42 was obtained from Aristro Pharmaceutical Ltd. Mandideep, Bhopal. All Metal salts $\mathrm{CuCl}_{2} .2 \mathrm{H}_{2} \mathrm{O}, \mathrm{NiCl} 2.4 \mathrm{H} 2 \mathrm{O}, \mathrm{CoCl} 2.6 \mathrm{H} 2 \mathrm{O}$, FeSO4.7H2O, $\mathrm{MnCl} 2.7 \mathrm{H} 2 \mathrm{O}, \mathrm{ZnCl} 2$ and $\mathrm{HgCl}_{2}$ were of Merck Chemicals. The solvents used were distilled water and methanol. Metal-ligand ratio was calculated using Systronics digital conductivity meter, IR spectra were obtained from CDRI Lucknow (Instrument used Perkin Elmer FTIR Spectrophotometer in the range of 4000$400 \mathrm{~cm}^{-1}$ ). Magnetic susceptibility measurements were received from CAT Indore (Instrument used-Vibrating Sample Magnetometer). Nitrogen was determined by the Dumas method and sulphur was estimated by the Messenger's method. The elemental microanalyses of $\mathrm{C}, \mathrm{H}$, and $\mathrm{N}$ for ligand were carried out with Thomas and Coleman Analyzer Carlo Erba 7106.

\section{Ligand - metal ratio}

To confirm the ligand-metal ratio, conductometric titrations using mono-variation method were carried out at $21{ }^{\circ} \mathrm{C} .0 .01 \mathrm{M}$ solution of omeprazole drug was prepared in 70:30 mixture of methanol and water. Similarly, $0.02 \mathrm{M}$ solutions of metal salts were prepared in the same solvent.The ligand was titrated against metal salt solutions using mono-variation method. Conductance was recorded after each addition. From the equivalence point in the graph, it has been concluded that the complex formation has taken place in the ratio of 2:1 (L:M) .Stability constants and free energy changes were also calculated by using Job's method[16] of continuous variation modified by Turner and Anderson[17].

\section{Synthesis of complexes}

The complexes were synthesized by mixing the solutions $(70 \%$ methanol) of metal salt with that of ligand in 1:2 molar ratios respectively. The thick precipitates of different colors for different metal salts were observed. By adjusting the $\mathrm{pH}$ with the addition of dilute $\mathrm{NaOH}$ solution and refluxing the mixtures for three and a half hours. Colored crystalline complexes were obtained. The complexes were filtered, washed with (70:30) mixture of methanol water and dried. Carbon, hydrogen, nitrogen, metal and water were estimated micro analytically at CDRI, Lucknow.

\section{RESULTS AND DISCUSSION}

The synthesized complexes are stable solids. They are soluble in DMF and DMSO and insoluble in all other organic solvents. Analytical data and conductometric studies suggest 2:1 [L: M] ratio. Measured conductance values of these complexes are too low to account for their electrolytic behavior. The magnetic studies indicate the $\mathrm{Mn}$ (II), $\mathrm{Co}(\mathrm{II}), \mathrm{Ni}(\mathrm{II}), \mathrm{Fe}(\mathrm{II})$ and $\mathrm{Cu}$ (II) complex to be paramagnetic while $\mathrm{Zn}$ (II) andHg(II) complexes to be diamagnetic.

I.R. Spectra: The vibrational spectra[18-21] for the free ligand omeprazole when compared with those of its complexes provided meaningful information regarding the bonding sites of the ligand (Table-2). The IR spectra of the complexes indicate that the ligand behaves as bidentate and co-ordinate to the metal via $\mathrm{C}=\mathrm{N}$ and sulphonic acid group. The shift of the $v \mathrm{C}=$ $\mathrm{N}$ and $\nu \mathrm{S}=\mathrm{O}$ by $10-15 \mathrm{~cm}^{-1}$ in the complexes indicates that these groups are involved in the complexation. In the IR spectra of omeprazole, strong band at $3456 \mathrm{~cm}^{-1}$ is assigned to secondary NH stretching vibrations. This band remains unaltered or shifted to the higher wave number in the complexes suggesting non-involvement of secondary $\mathrm{NH}$ group in coordination with metal ions. The medium to strong bands appearing at $1585 \mathrm{~cm}^{-1}$ in the free ligand are assigned to $\mathrm{C}=\mathrm{N}$ stretching vibration of the azomethine group based on the available reports. This band shifts to lower wave number in all the complexes by about $10-15 \mathrm{~cm}^{-1}$ indicates involvement of the azomethine $\mathrm{N}$ in bonding. Theshifting of $\mathrm{S}=\mathrm{O}$ stretching vibration to the lower wave number as compared to the free ligand is indicative of participation of sulphonic acid group in coordination. 
Table 1 : Analytical data of Complexes

\begin{tabular}{|c|c|c|c|c|c|c|c|c|}
\hline \multirow[b]{2}{*}{ S. No. } & \multirow{2}{*}{$\begin{array}{l}\text { Composition of Complex } \\
\text { (m-wt.) }\end{array}$} & \multirow{2}{*}{ Color } & \multirow{2}{*}{$\begin{array}{c}\text { Yield } \\
\%\end{array}$} & \multirow{2}{*}{$\underset{{ }^{0} \mathrm{C}}{\text { m.p. }}$} & \multicolumn{4}{|c|}{ Elemental Analyses (\%) : Found (Cal) } \\
\hline & & & & & $\mathrm{C}$ & $\mathbf{H}$ & $\mathbf{N}$ & M \\
\hline 1 & $\begin{array}{c}\left(\mathrm{C}_{17} \mathrm{H}_{19} \mathrm{~N}_{3} \mathrm{O}_{3} \mathrm{~S}\right) \\
(345.42)\end{array}$ & White & & 156 & 52.71 & 3.05 & 11.05 & - \\
\hline 2 & $\begin{array}{c}\left(\mathrm{C}_{17} \mathrm{H}_{19} \mathrm{~N}_{3} \mathrm{O}_{3} \mathrm{~S}\right)_{2} \mathrm{Mn} .\left(\mathrm{H}_{2} \mathrm{O}\right)_{2} \\
(781.801)\end{array}$ & $\begin{array}{c}\text { Pinkish } \\
\text { White }\end{array}$ & 48 & 205 & $\begin{array}{c}52.23 \\
(53.20)\end{array}$ & $\begin{array}{c}4.89 \\
(4.51)\end{array}$ & $\begin{array}{l}10.74 \\
(10.47)\end{array}$ & $\begin{array}{c}7.02 \\
(7.12)\end{array}$ \\
\hline 3 & $\begin{array}{c}\left(\mathrm{C}_{17} \mathrm{H}_{19} \mathrm{~N}_{3} \mathrm{O}_{3} \mathrm{~S}\right)_{2} \mathrm{Fe} \cdot\left(\mathrm{H}_{2} \mathrm{O}\right)_{2} \\
(782.710)\end{array}$ & Maroon & 86 & 220 & $\begin{array}{c}52.17 \\
(52.00)\end{array}$ & $\begin{array}{c}4.89 \\
(4.91)\end{array}$ & $\begin{array}{l}10.73 \\
(10.67)\end{array}$ & $\begin{array}{c}7.13 \\
(7.91)\end{array}$ \\
\hline 4 & $\begin{array}{c}\left(\mathrm{C}_{17} \mathrm{H}_{19} \mathrm{~N}_{3} \mathrm{O}_{3} \mathrm{~S}\right)_{2} \mathrm{Co} .\left(\mathrm{H}_{2} \mathrm{O}\right)_{2} \\
(785.796)\end{array}$ & Pink & 66 & 212 & $\begin{array}{c}51.96 \\
(36.90) \\
\end{array}$ & $\begin{array}{r}4.87 \\
(4.91) \\
\end{array}$ & $\begin{array}{c}10.69 \\
(10.67)\end{array}$ & $\begin{array}{c}7.49 \\
(7.69)\end{array}$ \\
\hline 5 & $\begin{array}{c}\left(\mathrm{C}_{17} \mathrm{H}_{19} \mathrm{~N}_{3} \mathrm{O}_{3} \mathrm{~S}\right)_{2} \mathrm{Ni} \cdot\left(\mathrm{H}_{2} \mathrm{O}\right)_{2} \\
(785.553)\end{array}$ & $\begin{array}{l}\text { Pista } \\
\text { Green }\end{array}$ & 71 & 175 & $\begin{array}{c}51.98 \\
(36.92) \\
\end{array}$ & $\begin{array}{r}4.87 \\
(4.95) \\
\end{array}$ & $\begin{array}{c}10.69 \\
(10.67)\end{array}$ & $\begin{array}{c}7.47 \\
(7.66) \\
\end{array}$ \\
\hline 6 & $\begin{array}{c}\left(\mathrm{C}_{17} \mathrm{H}_{19} \mathrm{~N}_{3} \mathrm{O}_{3} \mathrm{~S}\right)_{2} \text { Cu. }\left(\mathrm{H}_{2} \mathrm{O}\right)_{2} \\
(790.363))\end{array}$ & Green & 62 & 199 & $\begin{array}{c}51.66 \\
(51.70) \\
\end{array}$ & $\begin{array}{c}4.84 \\
(4.91) \\
\end{array}$ & $\begin{array}{c}10.63 \\
(10.77) \\
\end{array}$ & $\begin{array}{c}8.03 \\
(8.91) \\
\end{array}$ \\
\hline 7 & $\begin{array}{c}\left(\mathrm{C}_{17} \mathrm{H}_{19} \mathrm{~N}_{3} \mathrm{O}_{3} \mathrm{~S}\right)_{2} \mathrm{Hg} \\
(891.732)\end{array}$ & White & 75 & 210 & $\begin{array}{c}45.79 \\
(45.91)\end{array}$ & $\begin{array}{c}4.29 \\
(4.30)\end{array}$ & $\begin{array}{c}9.42 \\
(9.22)\end{array}$ & $\begin{array}{c}22.49 \\
(23.01)\end{array}$ \\
\hline 8 & $\begin{array}{c}\left(\mathrm{C}_{17} \mathrm{H}_{19} \mathrm{~N}_{3} \mathrm{O}_{3} \mathrm{~S}\right)_{2} \mathrm{Zn} \\
(756.22)\end{array}$ & White & 77 & 215 & $\begin{array}{c}54.00 \\
(54.91)\end{array}$ & $\begin{array}{c}5.06 \\
(5.30)\end{array}$ & $\begin{array}{c}11.11 \\
(11.21)\end{array}$ & $\begin{array}{c}8.64 \\
(8.01)\end{array}$ \\
\hline
\end{tabular}

Table 2: Stability Constant, Free Energy Change, Molar Conductance and Magnetic- Moment Data of Complexes

\begin{tabular}{|c|c|c|c|c|c|}
\hline S. No. & $\begin{array}{l}\text { Composition of Complex } \\
\text { (m-wt.) }\end{array}$ & $\begin{array}{c}\text { Stability } \\
\text { constant } \\
\operatorname{logK}(\mathrm{L} / \mathrm{mole})\end{array}$ & $\begin{array}{c}\text { Free Energy } \\
\text { change } \\
-\Delta \mathbf{F} \\
\text { (Kcal } / \text { mole) }\end{array}$ & $\begin{array}{c}\text { Molar } \\
\text { conductance } \\
\left(\mathrm{ohm}^{-1} \mathrm{~cm}^{2} \mathrm{~mol}^{-1}\right)\end{array}$ & $\begin{array}{c}\text { Magnetic } \\
\text { Moment } \\
\text { (B.M.) }\end{array}$ \\
\hline 1. & $\left(\mathrm{C}_{17} \mathrm{H}_{19} \mathrm{~N}_{3} \mathrm{O}_{3} \mathrm{~S}\right)_{2} \mathrm{Zn}$ & 10.7471 & 15.9751 & 14.6 & \\
\hline 2. & $\left(\mathrm{C}_{17} \mathrm{H}_{19} \mathrm{~N}_{3} \mathrm{O}_{3} \mathrm{~S}\right){ }_{2} \mathrm{Hg}$ & 10.5231 & 14.9751 & 10.34 & \\
\hline 3. & $\left(\mathrm{C}_{17} \mathrm{H}_{19} \mathrm{~N}_{3} \mathrm{O}_{3} \mathrm{~S}\right)_{2} \mathrm{Fe} \cdot\left(\mathrm{H}_{2} \mathrm{O}\right)_{2}$ & 11.1692 & 15.9466 & 10.6 & 5.20 \\
\hline 4. & $\left(\mathrm{C}_{17} \mathrm{H}_{19} \mathrm{~N}_{3} \mathrm{O}_{3} \mathrm{~S}\right)_{2} \mathrm{Mn} .\left(\mathrm{H}_{2} \mathrm{O}\right)_{2}$ & 12.088 & 17.03 & 12.01 & 5.62 \\
\hline 5. & $\left(\mathrm{C}_{17} \mathrm{H}_{10} \mathrm{~N}_{3} \mathrm{O}_{3} \mathrm{~S}\right)_{2} \mathrm{Cu} .\left(\mathrm{H}_{2} \mathrm{O}\right)_{2}$ & 11.1704 & 15.5905 & 13.0 & 1.75 \\
\hline 6. & $\left(\mathrm{C}_{17} \mathrm{H}_{19} \mathrm{~N}_{3} \mathrm{O}_{3} \mathrm{~S}\right)_{2}$ Ni. $\left(\mathrm{H}_{2} \mathrm{O}\right)_{2}$ & 11.4204 & 16.1746 & 12.13 & 3.06 \\
\hline 7. & $\left(\mathrm{C}_{17} \mathrm{H}_{19} \mathrm{~N}_{3} \mathrm{O}_{3} \mathrm{~S}\right)_{2} \mathrm{Co} .2 \mathrm{H}_{2} \mathrm{O}$ & 11.4208 & 16.039 & 14.08 & 4.65 \\
\hline
\end{tabular}

Table 3: IR Absorption data of the complexes

\begin{tabular}{|c|c|c|c|c|c|c|}
\hline Ligand and complex & $\begin{array}{c}v(\mathrm{NH}) \\
\mathrm{cm}^{-1}\end{array}$ & $\begin{array}{c}v(C=N) \\
\mathrm{cm}^{-1}\end{array}$ & $\begin{array}{c}v(S=O) \\
\mathrm{cm}^{-1}\end{array}$ & $\begin{array}{c}v(\mathrm{M}-\mathrm{N}) \\
\mathrm{cm}^{-}{ }^{1}\end{array}$ & $\begin{array}{c}v(\mathrm{M}-\mathrm{O}) \\
\mathrm{cm}^{-1}\end{array}$ & $\begin{array}{c}v\left(\mathrm{H}_{2} \mathrm{O}\right) \\
\mathrm{cm}^{-1}\end{array}$ \\
\hline $\mathrm{C}_{17} \mathrm{H}_{19} \mathrm{~N}_{3} \mathrm{O}_{3} \mathrm{~S}$ & 3456 & 1585 & 1070 & - & - & - \\
\hline$\left(\mathrm{C}_{17} \mathrm{H}_{19} \mathrm{~N}_{3} \mathrm{O}_{3} \mathrm{~S}\right)_{2} \mathrm{Fe} \cdot\left(\mathrm{H}_{2} \mathrm{O}\right)_{2}$ & 3459 & 1576 & 1045 & 415 & 610 & 3565 \\
\hline $\left.\mathrm{C}_{17} \mathrm{H}_{19} \mathrm{~N}_{3} \mathrm{O}_{3} \mathrm{~S}\right)_{2} \mathrm{Mn} \cdot\left(\mathrm{H}_{2} \mathrm{O}\right)_{2}$ & 3469 & 1572 & 1055 & 412 & 609 & 3535 \\
\hline $\left.\mathrm{C}_{17} \mathrm{H}_{19} \mathrm{~N}_{3} \mathrm{O}_{3} \mathrm{~S}\right)_{2} \mathrm{Ni} \cdot\left(\mathrm{H}_{2} \mathrm{O}\right)_{2}$ & 3465 & 1568 & 1035 & 410 & 617 & 3544 \\
\hline $\left.\mathrm{C}_{17} \mathrm{H}_{19} \mathrm{~N}_{3} \mathrm{O}_{3} \mathrm{~S}\right)_{2} \mathrm{Co} .\left(\mathrm{H}_{2} \mathrm{O}\right)_{2}$ & 3462 & 1560 & 1042 & 422 & 624 & 3545 \\
\hline $\left.\mathrm{C}_{17} \mathrm{H}_{19} \mathrm{~N}_{3} \mathrm{O}_{3} \mathrm{~S}\right)_{2} \mathrm{Cu} .\left(\mathrm{H}_{2} \mathrm{O}\right)_{2}$ & 3466 & 1565 & 1048 & 417 & 621 & 3557 \\
\hline$\left(\mathrm{C}_{17} \mathrm{H}_{10} \mathrm{~N}_{3} \mathrm{O}_{3} \mathrm{~S}\right)_{2} \mathrm{Zn}$ & 3468 & 1570 & 1050 & 426 & 615 & - \\
\hline $\left.\mathrm{C}_{17} \mathrm{H}_{19} \mathrm{~N}_{3} \mathrm{O}_{3} \mathrm{~S}\right)_{2} \mathrm{Hg}$ & 3456 & 1575 & 1047 & 428 & 609 & \\
\hline
\end{tabular}

Table 4: Antibacterial Activity - Zone of Inhibition $\{$ in $\mathrm{mm}\}$

\begin{tabular}{|c|c|c|c|c|c|}
\hline S. No. & Compound & P. Aeroginosa & S. Aureus & A. niger & A. flavous \\
\hline & $\mathrm{OM}$ & 9.2 & 11.5 & 11.22 & 12.11 \\
\hline & $\mathrm{Hg} \mathrm{L}_{2}$ & 20.9 & 19.8 & 21.11 & 18.50 \\
\hline & $\mathrm{Zn} \mathrm{L}_{2}$ & 11.7 & 13.3 & 12.80 & 19.00 \\
\hline & $\mathrm{Cu} \mathrm{L}_{2}\left(\mathrm{H}_{2} \mathrm{O}\right)_{2}$ & 12.6 & 14.7 & 17.33 & 15.80 \\
\hline & $\mathrm{Ni} \mathrm{L}_{2}\left(\mathrm{H}_{2} \mathrm{O}\right)_{2}$ & 10.7 & 10.8 & 11.77 & 14.33 \\
\hline & $\mathrm{Co} \mathrm{L}_{2}\left(\mathrm{H}_{2} \mathrm{O}\right)_{2}$ & 8.8 & 5.6 & - & 14.33 \\
\hline & $\mathrm{Mn} \mathrm{L}_{2}\left(\mathrm{H}_{2} \mathrm{O}\right)_{2}$ & --- & 12.2 & 6.60 & - \\
\hline & $\mathrm{Fe} \mathrm{L}_{2}\left(\mathrm{H}_{2} \mathrm{O}\right)_{2}$ & 13.9 & 15.1 & 13.00 & 12.12 \\
\hline & Std I Gentamycin & 17.4 & 20.5 & - & - \\
\hline & Std II Grisofulvin & 6.9 & 8.0 & 20.12 & 21.33 \\
\hline
\end{tabular}


The weak intensity non-ligand bands observed in the complexes in the regions $625-608 \mathrm{~cm}^{-1}$ and $429-409$ are assigned to $v(\mathrm{M}-\mathrm{N})$ and $v(\mathrm{M}-\mathrm{O})$ stretching vibrations, respectively. Band appearing at region $3654-3619 \mathrm{~cm}^{-1}$ due to coordinated water molecules and new band at $1380-1390 \mathrm{~cm}^{-1}$ in complexes might be due to chelate ring formation in them. data

\section{Electronic spectra and magnetic susceptibility}

The electronic spectra of the Ni(II), Co(II), $\mathrm{Mn}$ (II), $\mathrm{Fe}(\mathrm{II})$ and $\mathrm{Cu}(\mathrm{II})$ complexes were taken in DMSO $\left(10-{ }^{3} \mathrm{M}\right)$ solution. The Co(II) complex exhibit two bands at $18,520 \mathrm{~cm}^{-1}$ andat $21,714 \mathrm{~cm}^{-1}$ respectively, assignableto ${ }^{4} \mathrm{~A}_{2 \mathrm{~g}}(\mathrm{~F}) \longleftarrow{ }^{4} \mathrm{~T}_{1 \mathrm{~g}}(\mathrm{~F})\left(\mathrm{v}_{2}\right)$ and ${ }^{4} \mathrm{~T}_{1 \mathrm{~g}}(\mathrm{P}) \leftarrow{ }^{4} \mathrm{~T}_{1 \mathrm{~g}}(\mathrm{~F})$ $\left(v_{3}\right)$ transitions which indicate octahedral[22] geometry of the complex. The proposed geometry is further confirmed by high $\mu_{\text {eff }}$ value in the range [23-24] 4.895.24 B.M.The $\mathrm{Ni}$ (II)complex exhibits two bands at 13,510 and $23750 \mathrm{~cm}^{-1}$ which are assigned to to $^{3} \mathrm{~T}_{1 \mathrm{~g}}(\mathrm{~F})$ $\leftarrow{ }^{3} \mathrm{~A}_{2 \mathrm{~g}}(\mathrm{P}) \quad\left(\mathrm{v}_{2}\right)$ and ${ }^{3} \mathrm{~T}_{1 \mathrm{~g}}(\mathrm{P}) \leftarrow{ }^{3} \mathrm{~A}_{2 \mathrm{~g}}(\mathrm{~F})\left(v_{3}\right)$ transitions indicating octahedral[22] geometry of the complex. The geometry of $\mathrm{Ni}$ (II) complex is further confirmed [23-24] by the high $\mu_{\text {eff }}$ value in the range 3.09-3.20 B.M. The electronic spectra of the paramagnetic $\mathrm{Mn}$ (II) complex displays three absorption bands at 24500,22670 and at $16,666 \mathrm{~cm}^{-1}$ which can be assigned to ${ }^{4} \mathrm{E}_{\mathrm{g}}(\mathrm{G})$ $\leftarrow{ }^{6} \mathrm{~A}_{1 \mathrm{~g}},{ }^{4} \mathrm{~T}_{2 \mathrm{~g}}(\mathrm{G}) \leftarrow{ }^{6} \mathrm{~A}_{1 \mathrm{~g}}$ and ${ }^{4} \mathrm{~T}_{1 \mathrm{~g}}(\mathrm{G}) \leftarrow{ }^{6} \mathrm{~A}_{1 \mathrm{~g}}$ transitions respectively indicating octahedral[22] geometry of the complex. The geometry of $\mathrm{Mn}(\mathrm{II})$ complex is further confirmed[23-24] by the high $\mu_{\text {eff }}$ value in the range 5.85-5.98 B.M.. The $\mathrm{Cu}(\mathrm{II})$ complex exhibits a single broad ,asymmetric band in region $12820 \mathrm{~cm}^{-1}$ may be assigned to ${ }^{2} \mathrm{~B}_{2 \mathrm{~g}} \leftarrow{ }^{2} \mathrm{~B}_{1 \mathrm{~g}},{ }^{2} \mathrm{E}_{2 \mathrm{~g}} \leftarrow{ }^{2} \mathrm{~B}_{1 \mathrm{~g}}$ transitions are in analogy with expected tetragonally distorted octahedral geometry. The broadness of the band may be due to dynamic and John-Tellor distortion. It is further supported by the high $\mu_{\text {eff }}$ value in the range 1.89-1.92 B. M.. The spectra of Fe(II) complex shows two bands at $28160 \mathrm{~cm}^{-1}$ and $21075 \mathrm{~cm}^{-1}$, The first band is assigned to charge transfer while the second band may be due to the transitions ${ }^{5} \mathrm{E}_{\mathrm{g}} \leftarrow{ }^{5} \mathrm{~T}_{2 \mathrm{~g}}$ indicating octahedral[22] geometry of the complex. The proposed geometry is further confirmed by high $\mu_{\text {eff }}$ value in the range [23-24] 5.92-5.24 B.M. As expected Zn(II) and Hg(II) complexes are diamagnetic. The complexes are suggested to be tetra-coordinated probably having tetrahedral geometry based on analytical, I.R. and conductance data.

\section{NMR Spectra}

The 1H NMR[25-26] spectra of the ligand has the expected characteristic signals. The $\mathrm{CH}_{3}$ proton shows singlet at $\delta 2.2$ and $\mathrm{O}-\mathrm{CH}_{2} \mathrm{CH}_{3}$ proton at $\delta 3.5$ ppm . The doublet peak observed at $\delta 4.36$ and $4.66 \mathrm{ppm}$ is attributed to $\mathrm{CH}_{2}$ protons. In addition, a multiplet peak at $\delta 6.9-8.3 \mathrm{ppm}$ may be due to aromatic protons and peak at $\delta 13.2$ may be due to $\mathrm{NH}$ proton of benzimidazole ring. Signals observed in the complexes at region of $\delta 8.18-8.23 \mathrm{ppm}$ due to the azomethine proton either remained unaffected or shifted slightly downfield with reference to those of the parent ligand and the position of signal due to $\mathrm{NH}$ proton remains unaffected in the complexes. The aromatic protons show downfield shifts in the complexes. These observations support the assigned structure to the complex.

Scanning Electron Micrographs [S. E. M.]: SEM of metal complexes indicate the presence of well defined crystals free from any shadow of the metal ion on their external surface. The representative micrographs of a) Ligand; $\left[\mathrm{C}_{17} \mathrm{H}_{19} \mathrm{~N}_{3} \mathrm{O}_{3} \mathrm{~S}\right]$ b) $\left[\mathrm{FeL}_{2}\left(\mathrm{H}_{2} \mathrm{O}\right)_{2}\right]$, c) $\left.\mathrm{CuL}_{2}\left(\mathrm{H}_{2} \mathrm{O}\right)_{2}\right]$, d) $\left.\mathrm{CoL}_{2}\left(\mathrm{H}_{2} \mathrm{O}\right)_{2}\right]$, e) $\left.\left.\operatorname{NiL}_{2}\left(\mathrm{H}_{2} \mathrm{O}\right)_{2}\right], \mathrm{f}\right)$ $\left.\mathrm{ZnL}_{2}\left(\mathrm{H}_{2} \mathrm{O}\right)_{2}\right]$ are shown in Fig.2
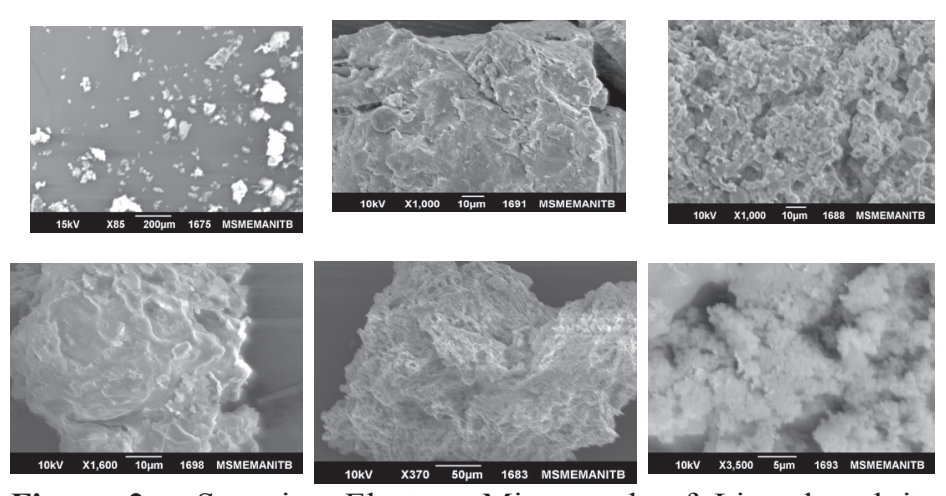

Figure 2 : Scanning Electron Micrograph of Ligand and its Complexes

\section{ESR Spectra}

ESR spectra of powdered samples of $\left[\mathrm{Cu}(\mathrm{OME})_{2}\left(\mathrm{H}_{2} \mathrm{O}\right)_{2}\right]$ complex was recorded at room temperature. When the monomeric species change into diametric species having axial symmetry and identical sites, the ' $\mathrm{g}$ ' values also change due to the change in symmetry[27] The spectra having asymmetric bands with two 'g' values $\mathrm{g}_{\|}$and $\mathrm{g}_{\perp}$. The trend $\mathrm{g}_{\|}>\mathrm{g}_{\perp}>\mathrm{g}$ (2.002), indicates that unpaired electron lies predominantly in the $\mathrm{d}_{\mathrm{x} 2-\mathrm{y} 2}$ orbital of copper (II) ion. The $g_{\|}>g_{\perp}>g$ (2.009) observed in the ' $g$ ' values suggests the presence of an unpaired 
electron in the $\mathrm{d}_{\mathrm{x} 2 \mathrm{-y} 2}$ orbital. The values of the $\sigma$ bonding parameter, $\alpha 2$, show appreciable covalence character in the metal-ligand bond. Based on these observations copper (II) complex may have octahedral geometry.

\section{X-RAY Diffraction}

The crystallinity of the material was analyzed with XRD with K-alpha radiation The X-ray diffraction of $\mathrm{Cu}$ (II) complex of $\mathrm{L}_{1}$ is studied as a representative system. The observed $2 \theta$ values with relative intensity more than $10 \%$ are indexed and have been used for evaluation. The X-ray diffraction pattern of the complex with respect to their prominent peaks has been indexed by using computer software[28]. The above index method also yielded miller indices $(\mathrm{h}, \mathrm{k}, \mathrm{l})$ values, unit cell parameters, volume of unit cell and space group. The observed values fit well with orthorhombic system to give a unit cell dimensions $\mathrm{a}=6.3314 \AA, \mathrm{b}=8.5059 \AA$ and $\mathrm{c}=15.405 \AA$.
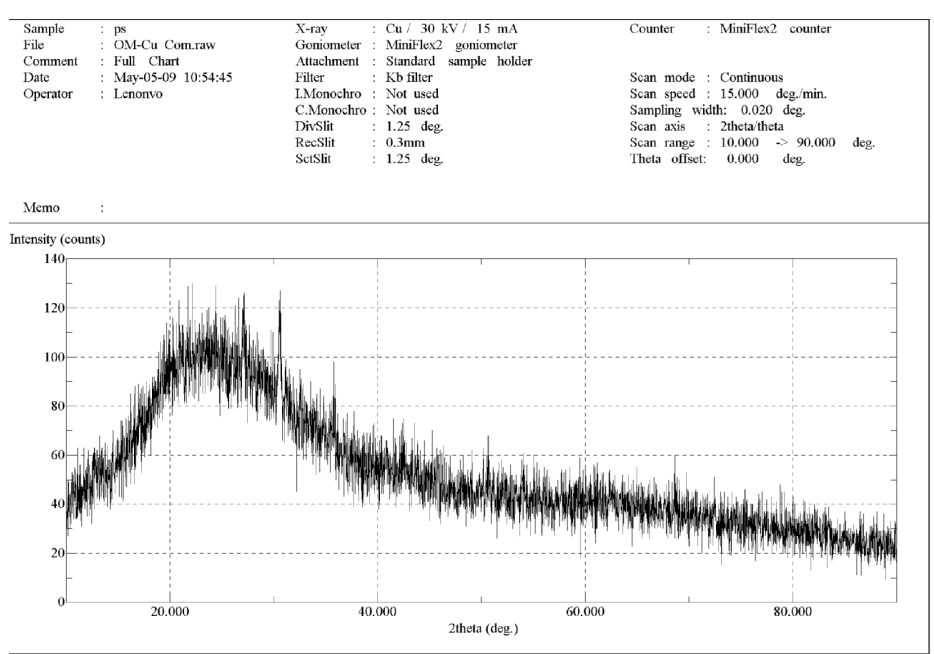

Figure 3: $\mathrm{XRD}$ graph for $\left[\mathrm{Cu}(\mathrm{OME})_{2} \cdot\left(\mathrm{H}_{2} \mathrm{O}\right)_{2}\right]$ complex

\section{Thermal analysis}

The thermal decompositions of the Ni(II)complex was studied using the TG and DSC technique. The thermo gravimetric studies of the complex was carried out in the temperature range $30-700^{\circ} \mathrm{C}$ with a sample heating rate $10^{\circ} \mathrm{C} / \mathrm{min}$ in air atmosphere. The weight-loss step between $175-200^{\circ} \mathrm{C}$ may correspond the elimination of coordinated water molecules. The weight-loss step between $250-450^{\circ} \mathrm{C}$ may be attributed to the loss of organic moiety of the complex molecule .The final decomposition continuous up to $700{ }^{\circ} \mathrm{C}$ and on further increasing the temperature no weight loss is observed which may be attributed to formation of stable metal oxide.

\section{Antimicrobial activity}

The antimicrobial activity of the ligand and the complexes was determined by the disc diffusion technique[29]. The compounds were screened in vitro against Pseudomonas, Staphylococcus aureus and two strain of fungi, Aspergillus niger and A. flavous. A 1mg/ $\mathrm{ml}$ solution in DMF was used. The standard used was gentamycin sulphate $1 \mathrm{mg} / \mathrm{ml}$ and solvent control was used to know the activity of the solvent. The bacterium was maintained on nutrient agar and the agar media were incubated for different microorganism culture tests. After $24 \mathrm{~h}$ of incubation at $37^{\circ} \mathrm{C}$ for bacteria and $72 \mathrm{~h}$ of incubation at $25^{\circ} \mathrm{C}$ for fungi, the diameter of zone of inhibition (mm) thus formed around each disc containing the test compound was measured accurately. All complexes show significant activity against bacteria Pseudomonas and Staphylococcus aureus as compared to ligand. The Co(II) complex is shown to be less active than the ligand in fungi Aspergillus niger and $\mathrm{Mn}$ (II) complex in fungi A.flavous. These preliminary results show that the activity of the ligand is enhanced when it is presented in the form of metal complex. Better activities of some metal complexes as compared to the ligand can be explained by chelation theory .The theory explains that decrease in polarizability of the metal could enhance the liphophilicity of the complexes which leads to the break- down of permeability of the cells resulting in interference with normal cell process. In view of the foregoing discussions, the high melting points and insolubility in common organic solvents, we have assigned following probable structure of the complexes of omeprazole.

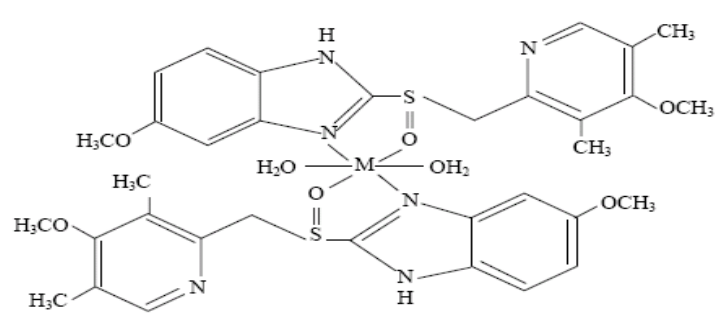

Figure 4: Structure of OME Complex with $\mathrm{Mn}(\mathrm{II}), \mathrm{Fe}(\mathrm{II}), \mathrm{Cu}(\mathrm{II}), \mathrm{C}$ o(II),Ni(II) Metals 


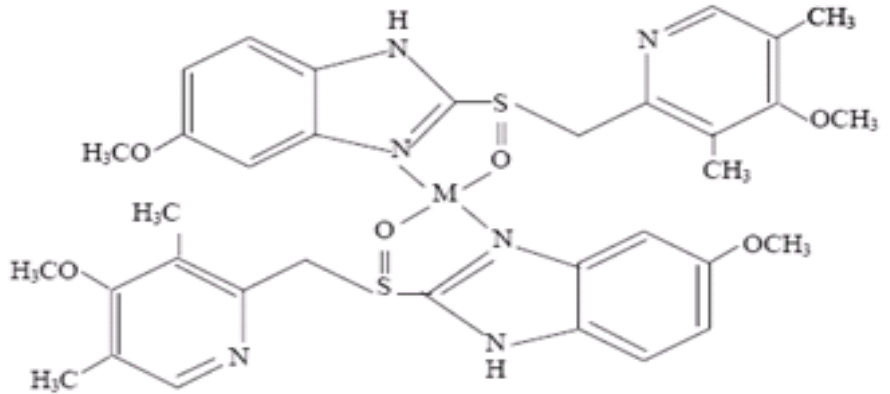

Figure 5: Structure of OME Complex with $\mathrm{Hg}(\mathrm{II})$ and $\mathrm{Zn}(\mathrm{II})$ Metals

Acknowledgement: The authors are thankful to Principal, Sadhu Vaswani College Bairagarh for providing necessary facilities for research work, DST for granting FIST program to the college and UGC for sanctioning UGC Research award to Dr. Suman Malik, one of the co-author

\section{REFERENCES}

[1] G. Biasco, M. Miglioli , L. Barbara, R. Corinaldesi , Am J Med., 129 (1998) 547-550.

[2] H. Soll , abstract Journal of the American Medical Association Vol. 275 (1996) 8.

[3] R. Kenneth, M.D. DeVault,O. Donald et .al. , American Journal of Gastroentrology 100 (2005) 190-200.

[4] Stuart Jon Spechler, The Mount Sinai Journal of Medicine Vol. 67 (2000) 106 - 111.

[5] Michael Brown and D. Russell Yang, Special Supplement Managed Care, 10 (2001) 7 - 10.

[6] T. Bruce Vanderhoff and M. Rundsarah Tahboub Journal of the American Academy of Family Physicians, 66(2002) 2 .

[7] C.W. Alan and C.Y. Mui Titus, Fan Hong Kong Med J., 136 (2007) 430-435.

[8] W. John Devlin,American Journal of HealthSystem Pharmacy, 62 (2005) S24- S29.

[9] Celine Vidaillac,Jean Guillon et. al., Journal of Antimicrobial Agents And Chemotherapy, 51(2007) 831-838.

[10] Reedijk , J. Pure Appl. Chem., 59(1987) 81.

[11] P. J. Lochrer and L. H. Einhorn, Ann.Inten. med., 100(1984)704.

[12] J. H. Toney, C.P. Brock and T.J. Marks, J. Am. Chem. Soc., 108(1986)7265.

[13] J. Forestier, J. Lab Clin Med., 20(1935)827-40.
[14] A. Bansal, and R.V. Singh, Synth.React.Inorg. Metal-Org.Chem., 31(2001) 381.

[15] A.Singh and P.Singh, Indian J. Chem. 39A (2000) 874.

[16] P. Job., Ann. Chim., 11 (1928), 113.

[17] S.E. Turner and R. C. Anderson., J. Am. Chem. Soc., 71 (1949) 912.

[18] K Nakamotto., Infrared Spectra of Inorganic and Co-ordination Compounds, (John Wiley), New York,(1976).

[19] I. Vogel , Quantitative Inorganic Analysis Longman, Green and Co. ,London, (1954) 455.

[20] L.J. Bellamy, Chemical Application of Spectroscopy (Int. Sci. Pub.) New York, (1956).

[21] Weissberge, Chem. Application of Spectroscopy (Int.Sci.Pub.) NewYork,(1956).

[22] C. H. Krishna, C.M. Maha patra and K.A. Dash , J. Inorg.Nucl.Chem.,39(1253) 1977.

[23] R. L. Carlin and A.J. VanDryneveledt, Magnetic Properties of Transition Metal Compounds, Springer- Verlag New York( 1997).

[24] B.N. Figgis , Introduction to Ligand Fields, Wiley Eastern Ltd., New Delhi , (1976) 279.

[25] M.Silverstein and G.C. Bassler, Spectrometric Identification of Organic Compounds. 2nd ed. Wiley, New York,(1967).

[26] H. Collins and, Lyne, Microbiological Methods.4th. Ed. Butterworth, London, (1976) 235.

[27] E. Kornkhe, Chem.Ber. , 88(1965) 863.

[28] Cheng Dong .Computer Software 'Powder X', Institute of Physics ,Chinese Academy of Science, Beijing 1000080

[29] C .H. Collins and Lye, Microbiological Methods.4th. Ed. Butterworth, London , (1976) 235. 